\title{
An influence of thermal treatment conditions of hydrotalcite-like materials on their catalytic activity in the process of $\mathrm{N}_{2} \mathrm{O}$ decomposition
}

\author{
Lucjan Chmielarz • Małgorzata Rutkowska • Piotr Kuśtrowski • \\ Marek Drozdek · Zofia Piwowarska • Barbara Dudek • \\ Roman Dziembaj $\cdot$ Marek Michalik
}

Received: 3 November 2010/Accepted: 3 January 2011/Published online: 25 February 2011

(C) The Author(s) 2011. This article is published with open access at Springerlink.com

\begin{abstract}
Hydrotalcite-like materials containing apart from magnesium and aluminum also copper, cobalt, nickel, and iron were prepared by a co-precipitation method. Thermal transformations of hydrotalcite-like materials were studied by thermal analysis methods as well as XRD, UV-vis-DRS, and XPS measurements of the samples calcined at various temperatures $\left(600,700\right.$, and $\left.800{ }^{\circ} \mathrm{C}\right)$. Calcined hydrotalcites, especially those containing cobalt and copper, were found to be active and selective catalysts of $\mathrm{N}_{2} \mathrm{O}$ decomposition. It was shown that an increase in the calcination temperature significantly activated the Co-containing catalysts. Promotion of the samples with potassium resulted in activation of the hydrotalcite-based catalysts.
\end{abstract}

Keywords Hydrotalcites - Mixed metal oxides . Thermal analysis $\cdot$ Catalysis $\cdot \mathrm{N}_{2} \mathrm{O}$ decomposition

\section{Introduction}

Hydrotalcites are layered double hydroxides (LDHs) which show the brucite-like network characteristic of $\left[\mathrm{Mg}(\mathrm{OH})_{2}\right]$. In brucite, $\mathrm{Mg}^{2+}$ ions are octahedrally coordinated by hydroxyl anions, giving rise to the edge-shared layers. Part of the $\mathrm{Mg}^{2+}$ cations is replaced by trivalent ions (e.g., $\mathrm{Al}^{3+}$ ), resulting in the positive charging of the brucite layers. This

L. Chmielarz $(\bowtie) \cdot$ M. Rutkowska · P. Kuśtrowski ·

M. Drozdek · Z. Piwowarska · B. Dudek · R. Dziembaj

Faculty of Chemistry, Jagiellonian University, Ingardena 3,

30-060 Kraków, Poland

e-mail: chmielar@chemia.uj.edu.pl

M. Michalik

Institute of Geological Sciences, Jagiellonian University,

Oleandry 2a, 30-063 Kraków, Poland charge is compensated by anions (e.g., $\mathrm{CO}_{3}{ }^{2-}$ ) which together with water molecules are located in the interlayer space of LDHs. Furthermore, some of $\mathrm{Mg}^{2+}$, as well as $\mathrm{Al}^{3+}$ ions can be replaced, respectively, by other di- (e.g., $\mathrm{Cu}, \mathrm{Co}$, and $\mathrm{Ni}$ ) and/or trivalent (e.g., $\mathrm{Ni}, \mathrm{Co}$, and $\mathrm{Fe}$ ) cations with similar radius. The hydrotalcite-like structures can be obtained for a relatively large group of di- and trivalent metal cations in a broad range of these metal loadings [1]. Thermal decomposition of hydrotalcite-like materials at middle temperatures $\left(T<600{ }^{\circ} \mathrm{C}\right)$ results in the formation of the relatively high surface mixed metal oxides, with a high dispersion of introduced transition metals oxide species [2-6]. An increase in the calcination temperature results in the aggregation of these species and formation of the spinel phases [2-6]. Therefore, hydrotalcite-like materials are excellent precursors for the preparation of the metal oxide catalysts of the desired chemical and phase composition. A great number of scientific papers presenting the studies of hydrotalcite-based materials as catalysts for various chemical processes was published. For example, $\mathrm{Cu}-\mathrm{Mg}-\mathrm{Al}$ mixed oxides were found to be active and selective catalysts for the DeNOx process [3] and selective catalytic oxidation of ammonia to nitrogen and water vapor [7]. Hydrotalcite-based mixed metal oxides modified with nickel were effective catalysts of steam methane reforming [8], while iron containing hydrotalcites were recognized as precursors of effective catalysts for ethylbenzene dehydrogenation [9].

The article presents the studies of hydrotalcite-like materials containing apart from magnesium and aluminum various transition metals. The hydrotalcite precursors were calcined at various temperatures and therefore the metal oxides samples with the different phase composition were produced. The obtained samples were tested in the role of the catalysts for the $\mathrm{N}_{2} \mathrm{O}$ decomposition, which is very sensitive for the phase composition of the metal oxide systems. 
The catalytic activity of various types of the metal oxides systems in the $\mathrm{N}_{2} \mathrm{O}$ decomposition was reported in the scientific literature. Cherlam et al. [10] showed high catalytic activity of $\mathrm{Co}_{3} \mathrm{O}_{4}$ spinel, which was additionally increased by partial substitution of another metal cation into the cobalt spinel structure $\left(\mathrm{M}_{x} \mathrm{Co}_{1-x} \mathrm{Co}_{2} \mathrm{O}_{4}, \mathrm{M}=\mathrm{Ni}\right.$ or $\mathrm{Mg}$ ) [11]. Recently, Russo et al. [12], who tested various spinel systems, reported high catalytic activity of $\mathrm{MgCo}_{2} \mathrm{O}_{4}$ and $\mathrm{ZnCo}_{2} \mathrm{O}_{4}$ spinels, which were more catalytically active than $\mathrm{Co}_{3} \mathrm{O}_{4}$. The activation effect of the $\mathrm{CeO}_{2}$ addition in $\mathrm{Co}_{3} \mathrm{O}_{4}$ spinel was shown by Xue et al. [13]. The best catalytic results were obtained for the molar ratio of $\mathrm{Ce} / \mathrm{Co}$ around 0.05 . On the other hand, also copper was found to be an active component of the catalysts for $\mathrm{N}_{2} \mathrm{O}$ composition. Dandekar et al. [14] studied an influence of the kind of the support on catalytic activity of the $\mathrm{Cu}$-containing catalysts. Centi et al. [15] reported the high activity of the copper-zirconia catalysts in $\mathrm{N}_{2} \mathrm{O}$ decomposition. The activity of these catalysts was comparable with that measured for ZSM-5 doped with copper. Also copper deposited on mesoporous silica was found to be the active catalyst for the $\mathrm{N}_{2} \mathrm{O}$ decomposition and reduction [16]. Hydrotalcite-like materials were reported to be very interesting precursors for synthesis of catalysts for $\mathrm{N}_{2} \mathrm{O}$ decomposition. Armor et al. [17] studied hydrotalcite-like materials containing apart from magnesium and aluminum also cobalt, nickel, rhodium, or palladium as precursors of catalysts for $\mathrm{N}_{2} \mathrm{O}$ decomposition. The best results were obtained for the $\mathrm{Co}-\mathrm{Al}$ sample with the $\mathrm{Co} / \mathrm{Al}$ ratio of 3 . Calcined $\mathrm{Co}-\mathrm{Mn}-\mathrm{Al}$ hydrotalcites were studied by Obalova et al. [18-20], who proposed the optimal method for synthesis of effective catalysts and reported high activity of these oxide systems in the presence of $\mathrm{O}_{2}$ and $\mathrm{NO}_{x}$. Chang et al. [21] reported high activity of calcined $\mathrm{Co}-\mathrm{Al}$ hydrotalcites containing additionally rhodium, palladium, or cerium in the process of $\mathrm{N}_{2} \mathrm{O}$ decomposition and reduction by carbon monoxide. Kannan and Swamy [22] reported that calcined $\mathrm{Co}-\mathrm{Al}$ hydrotalcites obtained by supersaturation method are more active in $\mathrm{N}_{2} \mathrm{O}$ decomposition than the samples produced by sequential saturation method.

The analysis of the literature data shows that the process of $\mathrm{N}_{2} \mathrm{O}$ decomposition is very sensitive to kind and loading of catalytically active transition metal, its form, dispersion and used support.

\section{Experimental}

Catalysts preparation

$\mathrm{Cu}$ (II)Mg(II)Al(III), $\quad \mathrm{Co}$ (II) $\mathrm{Mg}$ (II)Al(III), $\quad \mathrm{Cu}$ (II)Co(II) $\mathrm{Mg}$ (II)Al(III), $\mathrm{Ni}$ (II)Mg(II)Al(III), and $\mathrm{Mg}$ (II)Fe(III)Al (III) hydrotalcite-like materials were prepared by the co-precipitation method using aqueous solutions of the following metal nitrates: $\mathrm{Mg}\left(\mathrm{NO}_{3}\right)_{2} \cdot 6 \mathrm{H}_{2} \mathrm{O}$ (Sigma), $\mathrm{Al}\left(\mathrm{NO}_{3}\right)_{3}$. $9 \mathrm{H}_{2} \mathrm{O}$ (Fluka), $\mathrm{Cu}\left(\mathrm{NO}_{3}\right)_{2} \cdot 3 \mathrm{H}_{2} \mathrm{O}$ (Merck), $\mathrm{Co}\left(\mathrm{NO}_{3}\right)_{2} \cdot 6 \mathrm{H}_{2} \mathrm{O}$ (POCh), $\mathrm{Ni}\left(\mathrm{NO}_{3}\right)_{2} \cdot 6 \mathrm{H}_{2} \mathrm{O}$ (Acros), and $\mathrm{Fe}\left(\mathrm{NO}_{3}\right)_{3} \cdot 9 \mathrm{H}_{2} \mathrm{O}$ (POCh). Solution of $\mathrm{NaOH}(\mathrm{POCh})$ was used as a precipitating agent. The mixture of metal nitrate solutions was slowly added to a vigorously stirred aqueous solution containing a slight excess of $\mathrm{Na}_{2} \mathrm{CO}_{3}$ (POCh). The $\mathrm{pH}$ was maintained constant at $10.0 \pm 0.2$ by dropwise addition of $\mathrm{NaOH}$ solution. An exception was Fe-containing hydrotalcite, which was synthesized at $\mathrm{pH} 8.5 \pm 0.2$. Precipitates were aged in a suspension at $60{ }^{\circ} \mathrm{C}$ for $30 \mathrm{~min}$ (or $40{ }^{\circ} \mathrm{C}$ for $\mathrm{Fe}$-hydrotalcite) under vigorous stirring. In the next step, the suspension was filtered, washed with distilled water, and dried overnight at $120{ }^{\circ} \mathrm{C}$. Finally, the prepared hydrotalcite-like materials were calcined at 600,700 , or $800{ }^{\circ} \mathrm{C}$ for $6 \mathrm{~h}$. The samples codes and the molar ratios of metals are shown in Table 1. A detailed description of the hydrotalcite preparation was presented in our previous papers $[2,3]$.

The hydrotalcites calcined at $800{ }^{\circ} \mathrm{C}$ were modified with potassium using the incipient wetness impregnation method. Aqueous solutions of $\mathrm{KNO}_{3}(\mathrm{POCh})$ were used for the deposition of potassium. The intended potassium content in the samples was 0.09 and $0.9 \mathrm{wt} \%$. The impregnated samples were calcined at $600{ }^{\circ} \mathrm{C}$.

\section{Catalysts characterization}

For the selected hydrotalcite-like samples, the TGA-DTA measurements were performed using a Mettler Tolledo $851^{\mathrm{e}}$ thermobalance system. The experiments were performed in a flow of pure argon $(80 \mathrm{~mL} / \mathrm{min})$ in the temperature range of $25-1,000{ }^{\circ} \mathrm{C}$ at a heating rate of $10{ }^{\circ} \mathrm{C} / \mathrm{min}$.

The surface area of hydrotalcite-like materials calcined at different temperatures was determined by the BET method. The measurements were performed using ASAP 2010 (Micromeritics). Prior to the nitrogen adsorption at $-196{ }^{\circ} \mathrm{C}$ the samples were outgassed under vacuum at $350{ }^{\circ} \mathrm{C}$ for $12 \mathrm{~h}$.

The X-ray diffraction (XRD) patterns of hydrotalcitelike materials and mixed metal oxides formed by their thermal decomposition were obtained with a Philips X'Pert APD diffractometer using $\mathrm{Cu} \mathrm{K}_{\alpha}$ radiation $(\lambda=$ $1.54178 \AA$ ).

The coordination and aggregation of transition metals present in mixed metal oxides as well as their hydrotalcite precursors were studied by UV-vis-DR spectroscopy using an Evolution 600 (Thermo) spectrophotometer. The measurements were performed in the range of $200-900 \mathrm{~nm}$ with a resolution of $2 \mathrm{~nm}$.

The surface composition of the calcined samples was studied by X-ray photoelectron spectroscopy (XPS). The 
Table 1 Samples codes, composition, calcination temperature, and surface area of the hydrotalcite-based samples

\begin{tabular}{|c|c|c|c|c|}
\hline Sample code & Composition & Atomic ratio & $\begin{array}{l}\text { Calcination } \\
\text { temperature } /{ }^{\circ} \mathrm{C}\end{array}$ & $\begin{array}{l}S_{\text {BET }} \text { of calcined } \\
\text { hydrotalcite } / \mathrm{m}^{2} / \mathrm{g}\end{array}$ \\
\hline HT600-Cu10 & $\mathrm{Cu} / \mathrm{Mg} / \mathrm{Al}$ & $10 / 61 / 29$ & 600 & 205 \\
\hline HT600-Cu15 & $\mathrm{Cu} / \mathrm{Mg} / \mathrm{Al}$ & $15 / 56 / 29$ & 600 & 250 \\
\hline HT700-Cu15 & $\mathrm{Cu} / \mathrm{Mg} / \mathrm{Al}$ & $15 / 56 / 29$ & 700 & 193 \\
\hline HT800-Cu15 & $\mathrm{Cu} / \mathrm{Mg} / \mathrm{Al}$ & $15 / 56 / 29$ & 800 & 88 \\
\hline HT600-Co10 & $\mathrm{Co} / \mathrm{Mg} / \mathrm{Al}$ & $10 / 61 / 29$ & 600 & 198 \\
\hline HT600-Co15 & $\mathrm{Co} / \mathrm{Mg} / \mathrm{Al}$ & $15 / 56 / 29$ & 600 & 244 \\
\hline HT700-Co15 & $\mathrm{Co} / \mathrm{Mg} / \mathrm{Al}$ & $15 / 56 / 29$ & 700 & 217 \\
\hline HT800-Co15 & $\mathrm{Co} / \mathrm{Mg} / \mathrm{Al}$ & $15 / 56 / 29$ & 800 & 61 \\
\hline HT600-Cu10Co10 & $\mathrm{Cu} / \mathrm{Co} / \mathrm{Mg} / \mathrm{Al}$ & $10 / 10 / 51 / 29$ & 600 & 158 \\
\hline HT700-Cu10Co10 & $\mathrm{Cu} / \mathrm{Co} / \mathrm{Mg} / \mathrm{Al}$ & $10 / 10 / 51 / 29$ & 700 & 111 \\
\hline HT800-Cu10Co10 & $\mathrm{Cu} / \mathrm{Co} / \mathrm{Mg} / \mathrm{Al}$ & $10 / 10 / 51 / 29$ & 800 & 63 \\
\hline HT600-Cu15Co15 & $\mathrm{Cu} / \mathrm{Co} / \mathrm{Mg} / \mathrm{Al}$ & $15 / 15 / 41 / 29$ & 600 & 114 \\
\hline HT600-Fe10 & $\mathrm{Fe} / \mathrm{Mg} / \mathrm{Al}$ & $10 / 61 / 29$ & 600 & 171 \\
\hline HT600-Ni10 & $\mathrm{Ni} / \mathrm{Mg} / \mathrm{Al}$ & $10 / 61 / 29$ & 600 & 226 \\
\hline
\end{tabular}

measurements were performed at a room temperature in the ultrahigh vacuum (UHV) surface analysis system (Prevac). An $\mathrm{Al} \mathrm{K}_{\alpha}$ monochromatized radiation at $1486.6 \mathrm{eV}$ and a hemispherical photoelectron energy analyzer (Scienta R3000) were used to determine the photoemission spectra. The XPS spectra were recorded with a pass energy of $100 \mathrm{eV}$. The data processing was performed with a CasaXPS, using a Shirley type background substraction and Gaussian/Lorentzian peak shapes. The binding energies were corrected by setting the $\mathrm{Mg} 2 \mathrm{p}$ peak at $50.5 \mathrm{eV}$, and the integrated intensities were corrected by atomic sensitivity factors.

\section{Catalytic tests}

The catalytic measurements of $\mathrm{N}_{2} \mathrm{O}$ decomposition were performed in a fixed-bed quartz microreactor at ambient pressure and in the range of temperatures $100-650{ }^{\circ} \mathrm{C}$. The composition of outlet gas was analyzed on-line using quadrupole mass spectrometer RGA 200 (Prevac) connected directly to the reactor outlet. For each experiment, $0.1 \mathrm{~g}$ of a catalyst was placed on quartz wool in the reactor (6 $\mathrm{mm}$ i.d., $l=365 \mathrm{~mm}$ ) and outgassed in a flow of pure helium at $500{ }^{\circ} \mathrm{C}$. After cooling the reactor to $100{ }^{\circ} \mathrm{C}$, the gas mixture containing 0.5 vol. $\% \mathrm{~N}_{2} \mathrm{O}$ and 4.5 vol. $\% \mathrm{O}_{2}$ in He was fed into the reactor using mass flow controllers (Brooks). The total rate of gas flow was set at $50 \mathrm{~mL} / \mathrm{min}$ and temperature was increased at a rate of $10^{\circ} \mathrm{C} / \mathrm{min}$.

\section{Results and discussion}

Table 1 shows composition and BET surface area of hydrotalcites calcined at different temperatures. In a series of the samples calcined at $600{ }^{\circ} \mathrm{C}$ the highest surface area was measured for HT600-Cu15 and HT600-Co15. In general, an increase in the transition metal content increased surface area of the calcined samples (with exception of the samples containing both copper and cobalt), whereas and increase in calcination temperature decreased their surface area.

The thermal decomposition of selected hydrotalcites (HT-Cu15, HT-Co15, and HT-Cu10Co10) was studied using thermogravimetric method. The results of these studies are presented in Fig. 1. The thermal decomposition of hydrotalcites consists of few stages. A decrease of the samples weight that occurred at temperature below $250{ }^{\circ} \mathrm{C}$, assisted by endothermic peak (DTA), is associated with the removal of the interlayer and weakly adsorbed water molecules [2]. For all the studied samples nearly this same weight loss (12.6-13.6 wt\%) in this stage was detected. It could be seen that removal of water from the HT-Cu15 sample was easier than for HT-Co15. Therefore, it seems that water molecules are more loosely bound to brucite-like sheets containing $\mathrm{Cu}$ cations. The next stage of the thermal decomposition of hydrotalcites is observed in the temperature range of $250-500{ }^{\circ} \mathrm{C}$. The loss of weight $(\sim 25 \%)$ is attributed to the decomposition of hydroxyl groups in the brucite-like layers, as well as the interlayer anions decomposition and removal. It could be seen that this stage of the hydrotalcite decomposition depended on the composition of the brucite-like sheets. In the case of the HT-Co15 sample, this process occurred in a relatively narrow temperature range of $220-420{ }^{\circ} \mathrm{C}$. For the coppercontaining samples (HT-Cu15 and HT-Cu10Co10), this stage of the hydrotalcites decomposition took place in a much broader temperature range from $210{ }^{\circ} \mathrm{C}$ to about 

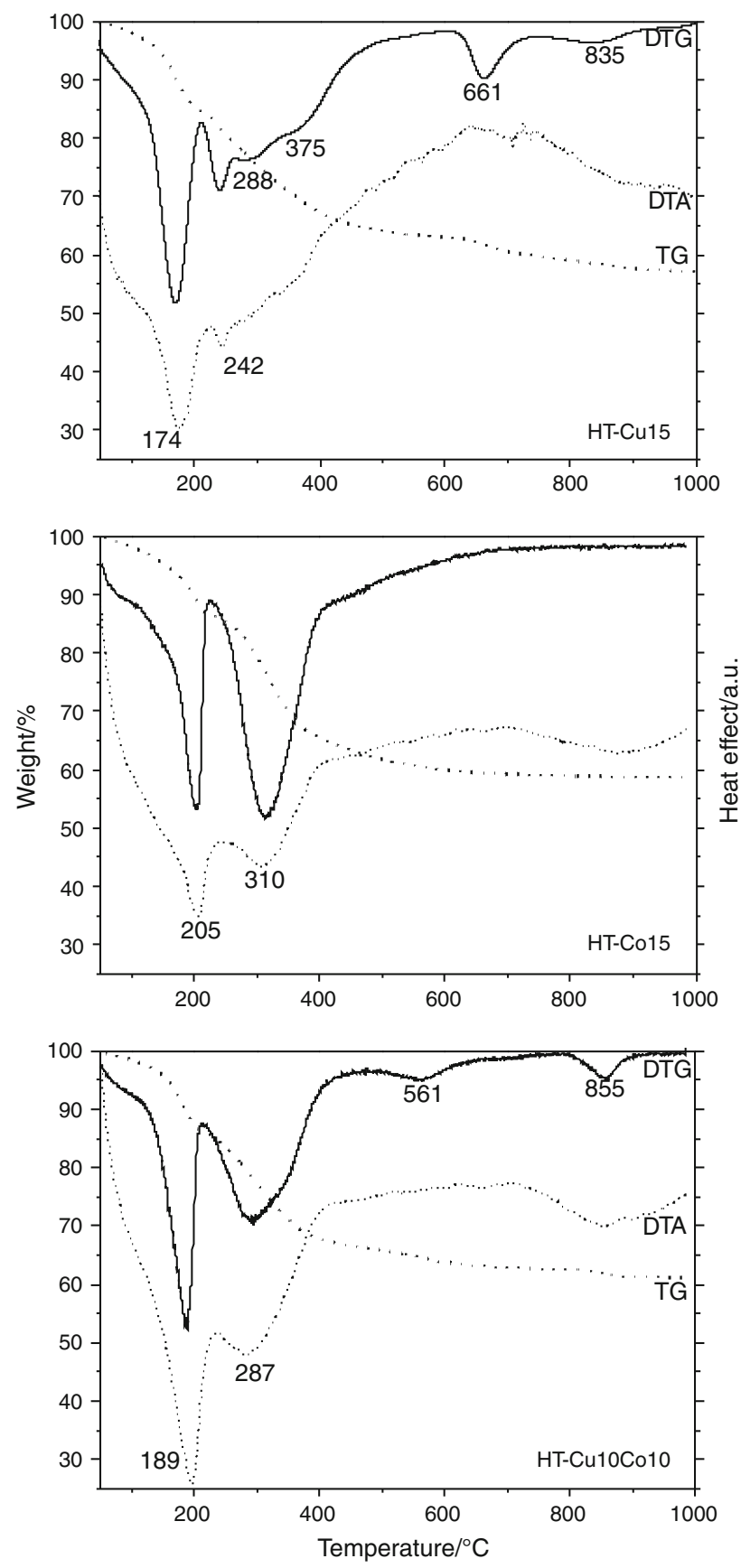

Fig. 1 Results of thermogravimetric analysis of hydrotalcite-like materials

$460-510{ }^{\circ} \mathrm{C}$ and proceeds in few steps. Two DTG peaks appeared for the $\mathrm{Cu}$-containing samples at higher temperatures. As it was shown in our previous studies [2], the peaks at 660 and $565{ }^{\circ} \mathrm{C}$ found in the DTG curve of HT-Cu15 and HT-Cu10Co10 are related to the thermal decomposition of strongly stabilized structural $\mathrm{CO}_{3}{ }^{2-}$ anions. Similar effect was reported for $\mathrm{Cu}-\mathrm{Mg}-\mathrm{Al}$ hydrotalcites by Auer et al. [23]. It seems that copper introduced into the hydrotalcite structure stabilizes the $\mathrm{CO}_{3}{ }^{2-}$ anions, which are decomposed at higher temperature. The DTG peaks at about $800-850{ }^{\circ} \mathrm{C}$ are probably related to the thermal reduction of $\mathrm{Cu}$ (II) cations to $\mathrm{Cu}$ (I). Such effect was earlier reported for $\mathrm{Cu}-\mathrm{Mg}-\mathrm{Al}$ hydrotalcite derived mixed metal oxide even in oxygen containing atmosphere [3].

The XRD patterns of the as-prepared and calcined hydrotalcite-like materials are shown in Fig. 2. The diffractograms of the as-prepared samples (HT-Cu15, HT-Co15, and HT-Cu10Co10) are characterized by the presence of reflections typical of the hydrotalcite structure [2]. The comparison of the intensities of XRD reflections shows that crystallinity of the HT-Cu15 sample is higher than HT-Co15 and HT-Cu10Co10 ones. Calcination of the samples at $600{ }^{\circ} \mathrm{C}$ resulted in a disappearance of diffraction lines typical of the hydrotalcite structure and formation of three new broad reflexes. Two of them, positioned at about $42^{\circ}$ and $62^{\circ}$, are characteristic of the $\mathrm{MgO}$ phase, whereas the band at about $37^{\circ}$ is attributed to the presence of the spinel phase $\mathrm{MgAl}_{2} \mathrm{O}_{4}[2,24]$. For the cobalt containing samples (HT600$\mathrm{Co} 15$ and $\mathrm{HT} 600-\mathrm{Cu} 10 \mathrm{Co} 10$ ), the reflection at about $37^{\circ} \mathrm{can}$ be also related to the presence of the $\mathrm{Co}_{3} \mathrm{O}_{4}$ and $\mathrm{CoO}$ phases (Fig. 2a, c), whereas for the copper-containing samples (HT600-Cu15 and HT600-Cu10Co10) that peak could be also attributed the $\mathrm{CuAl}_{2} \mathrm{O}_{4}$ and $\mathrm{CuO}$ phases (Fig. 2b, c). An increase of the calcination temperature to $700{ }^{\circ} \mathrm{C}$ resulted in an appearance of new reflections characteristic of the mentioned above metal oxide and spinel phases, whereas in diffractograms of the samples calcined at $800{ }^{\circ} \mathrm{C}$ the sharp and intensive peaks typical of the metal oxide and spinel phases suggest a significant increase of their crystallinity.

Therefore, it could be concluded that calcination of hydrotalcite-like materials at $600{ }^{\circ} \mathrm{C}$ results in their transformation into poorly crystalline mixed metal oxides. An increase in the calcination temperature to $700{ }^{\circ} \mathrm{C}$ results in the formation of the spinel phases, which become more ordered after calcination of the samples at $800{ }^{\circ} \mathrm{C}$.

The UV-vis-DRS measurements were performed for hydrotalcite-like materials calcined at different temperatures. The samples were analyzed in the wavelength range of 200-900 nm at room temperature (Fig. 3). The as-synthesized copper-containing samples were blue, while hydrotalcites containing cobalt were pink. An increase in the cobalt content in the calcined samples resulted in a very deep green color (nearly black). To carry out the UV-vis-DRS measurements, the samples were diluted in commercial silica gel (silica gel/sample ratio was 9:1).

The UV-vis-DR spectrum of the as-synthesized Co-containing hydrotalcite shows the specific band at around $520 \mathrm{~nm}$ (Fig. 3a). This absorption band is related to the presence of $\mathrm{Co}^{2+}$ cations in the octahedral coordination located in the brucite-like layers [25, 26]. This fact explains also the pink color of the samples. The broad band in the 

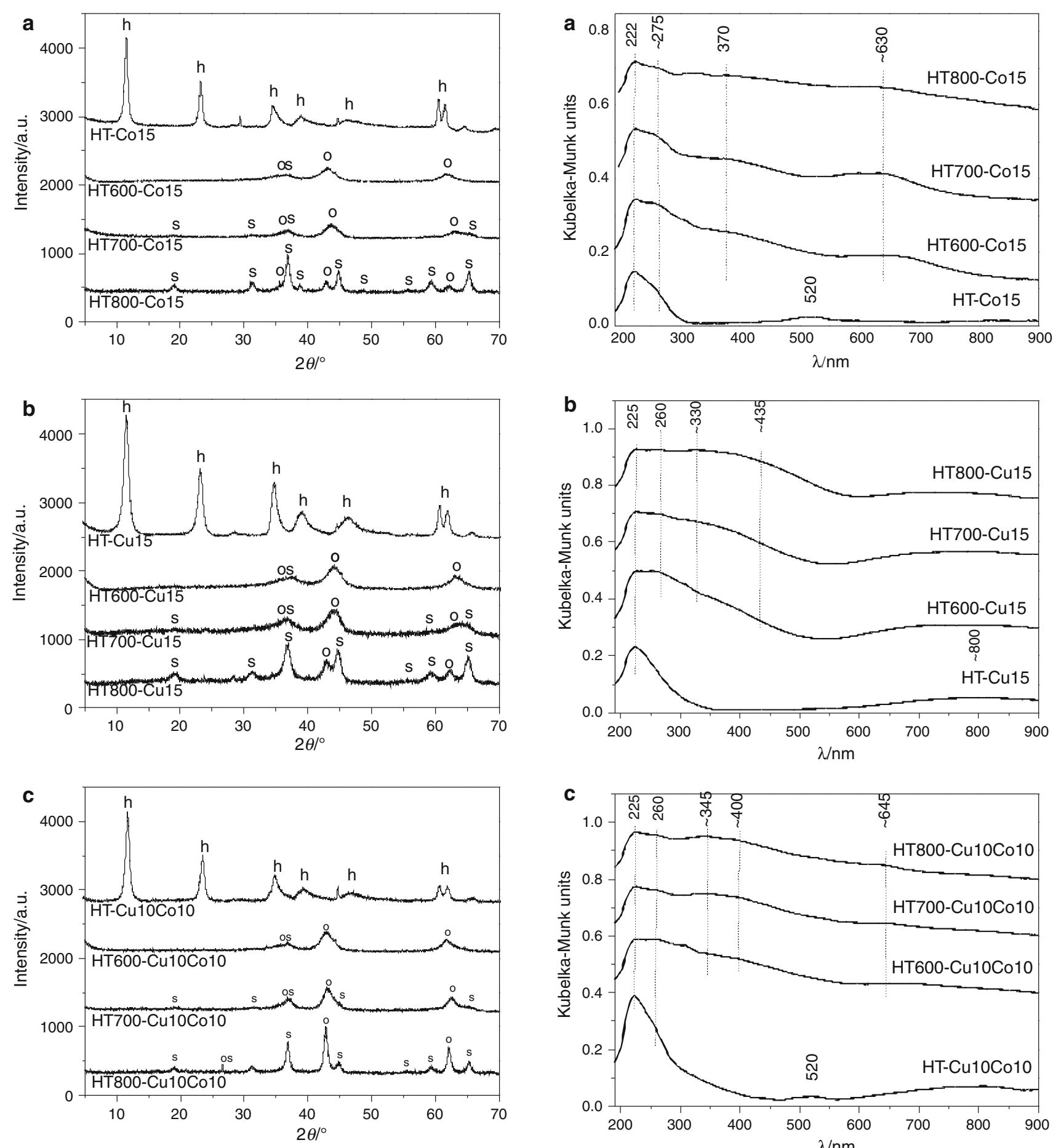

Fig. 2 Diffractograms of hydrotalcite-like samples calcined at different temperatures: $h$ hydrotalcite, $o$ metal oxides, $s$ spinels

range of $600-700 \mathrm{~nm}$ can be found in the spectrum of the calcined cobalt-containing samples. This band is attributed to the $d-d$ transitions in octahedrally coordinated $\mathrm{Co}^{3+}$ cations (transition ${ }^{1} \mathrm{~T}_{1 \mathrm{~g}}$ (I) $\leftarrow{ }^{1} \mathrm{~A}_{\mathrm{g}}(\mathrm{I})$ ) [26]. It should be noted that this absorption band is absent in the spectrum of as-synthesized hydrotalcite, so the thermal treatment

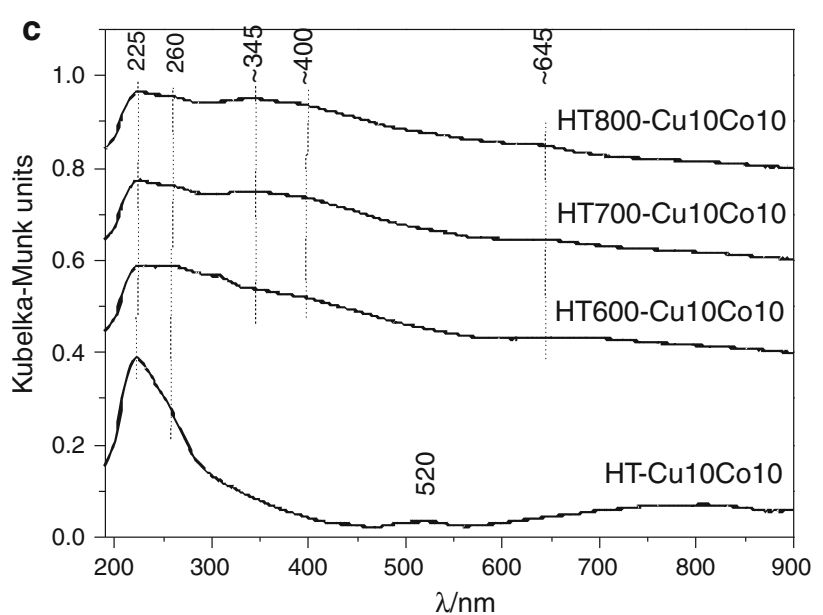

Fig. 3 UV-vis-DR spectra of hydrotalcite-like materials calcined at different temperatures

(darker, nearly black color of the sample) results in a partial oxidation of $\mathrm{Co}^{2+}$ to $\mathrm{Co}^{3+}$. Probably, the increased calcination temperature provoked the $\mathrm{Co}_{3} \mathrm{O}_{4}$ spinel formation. The absorption band at around $370 \mathrm{~nm}$, which appeared only in the spectrum of the calcined samples, also proves the existence of the $\mathrm{Co}^{3+}$ cations in the octahedral 
coordination (transition ${ }^{1} \mathrm{~T}_{2 \mathrm{~g}}$ (I) $\leftarrow{ }^{1} \mathrm{~A}_{\mathrm{g}}$ (I)) [26]. Usually, the band at around $230-250 \mathrm{~nm}$ results from the oxygen to metal charge transfer [27].

Figure $3 \mathrm{~b}$ shows the UV-vis-DR spectra recorded for a series of the $\mathrm{Cu}$-containing samples. The spectrum of as-synthesized hydrotalcite shows the intensive band at about $225 \mathrm{~nm}$, which can be attributed to the metal to ligand charge transfer (transition $\mathrm{O}^{2-} \leftarrow \mathrm{Cu}^{2+}$ ). The broad shoulder around $800 \mathrm{~nm}$ is associated with the $\mathrm{Cu}^{2+}$ transition in the octahedral coordination, while the band located at $680 \mathrm{~nm}$ is related to the $\mathrm{Cu}^{2+}$ transition in the deformed octahedral coordination [28]. The UV-vis-DR spectra of the calcined $\mathrm{Cu}$-containing samples show the band at about $260 \mathrm{~nm}$, which is related to the presence of $\mathrm{Cu}^{2+}$ and $\mathrm{Al}^{3+}$ in the spinel like structure (transition ${ }^{2} \mathrm{E}_{\mathrm{g}} \leftarrow{ }^{2} \mathrm{~T}_{2 \mathrm{~g}}$ ) [28]. The band at $330 \mathrm{~nm}$ could be assigned to the charge transfer between $\mathrm{Cu}^{2+}$ and oxygen in oligomeric metal oxide species $[\mathrm{Cu}-\mathrm{O}-\mathrm{Cu}]_{n}$. The broad band at around $435 \mathrm{~nm}$ is related to the $d-d$ transfer in bulky $\mathrm{CuO}$.

Figure $3 \mathrm{c}$ shows the UV-vis-DR spectra recorded for a series of the samples containing both cobalt and copper. It should be noted that these spectra are characterized by the presence of the bands typical of the transitions occurred in cobalt and copper species, which were found in the samples containing only one of these transition metals (cf. Fig. 3a, b).

The UV-vis-DRS studies proved that calcination of the hydrotalcite samples resulted in the formation of the aggregated metal oxide and spinel phases. These results are fully consistent with the results of XRD analysis of the samples.

XPS spectra were recorded for the selected samples (HT-Cu15 and HT-Co15) after calcination at 600 and $800{ }^{\circ} \mathrm{C}$ as well as modification with potassium. The collected results are summarized in Table 2. The calcined
$\mathrm{Cu}-$ and Co-containing hydrotalcites showed peaks at 935.1-935.4 eV (Cu 2p $\left.\mathrm{p}_{3 / 2}\right)$ and 780.3-780.6 eV (Co 2p $\left.\mathrm{p}_{3 / 2}\right)$, respectively, characteristic of $\mathrm{Cu}^{2+}$ cations in $\mathrm{CuAl}_{2} \mathrm{O}_{4}$ [29] and $\mathrm{Co}^{2+} / \mathrm{Co}^{3+}$ in $\mathrm{Co}_{3} \mathrm{O}_{4}$ and $\mathrm{CoAl}_{2} \mathrm{O}_{4}$ [30]. It can be found that the content of transition metals at the sample surface, especially in the case of copper-loaded samples, is significantly lower compared to that in bulk. Such phenomenon was previously observed by Bridier et al. [31] for calcined $\mathrm{Cu}-\mathrm{Al}$ hydrotalcites and was explained by segregation of transition metal penetrating the interior of alumina. An interesting effect was observed for the $\mathrm{O} 1 \mathrm{~s}$ core level peak, which can be clearly deconvoluted into two components assigned to $\mathrm{O}^{2-}$ lattice oxygen (at lower binding energy) and to oxygen of hydroxyl group (at higher binding energy). The contribution of lattice oxygen form increased both for the HT-Cu15 and HT-Co15 sample after raising the calcination temperature from 600 to $800{ }^{\circ} \mathrm{C}$. An introduction of potassium to the catalyst calcined at $800{ }^{\circ} \mathrm{C}$ resulted in an increase of amount of hydroxyl groups present on the sample surface. Higher binding energies of $\mathrm{O} 1 \mathrm{~s}$ photoelectron line measured for the $\mathrm{Cu}$-doped samples compared to that characteristic of Co-containing ones confirm additionally enrichment of the HT-Cu15 sample in aluminum.

The calcined hydrotalcite-like materials were examined as catalyst for the $\mathrm{N}_{2} \mathrm{O}$ decomposition. Nitrogen and oxygen were the only detected products of this process. Figure 4 shows the $\mathrm{N}_{2} \mathrm{O}$ conversion measured in the presence of the catalysts containing various transition metals and calcined at $600{ }^{\circ} \mathrm{C}$. The catalytic activity of these samples can be ordered as: HT600-Cu10 > HT600-Co10 > HT600-Fe10 > HT600-Ni10. As the copper- and cobaltcontaining samples were found to be significantly more active catalysts compared to the $\mathrm{Fe}$ - and Ni-loaded ones, the

Table 2 Binding energies of the main peaks and surface composition for the calcined samples

\begin{tabular}{|c|c|c|c|c|c|c|c|}
\hline \multirow[t]{2}{*}{ Sample } & \multicolumn{5}{|c|}{ Photoelectron line positions } & \multicolumn{2}{|c|}{ Molar ratio } \\
\hline & $\mathrm{Cu} 2 \mathrm{p}_{3 / 2}$ & Co $2 p_{3 / 2}$ & $\mathrm{O} 1 \mathrm{~s}$ & $\mathrm{Al} 2 \mathrm{p}$ & $\operatorname{Mg} 2 p$ & $\mathrm{M}^{\mathrm{a}} / \mathrm{Al}$ & $\mathrm{Mg} / \mathrm{Al}$ \\
\hline HT600-Cu15 & 935.4 & - & $\begin{array}{l}531.1(37 \%) \\
532.6(63 \%)\end{array}$ & 74.7 & 50.5 & 0.07 & 1.20 \\
\hline HT800-Cu15 & 935.1 & - & $\begin{array}{l}531.3(46 \%) \\
532.6(54 \%)\end{array}$ & 74.7 & 50.5 & 0.11 & 1.16 \\
\hline HT800-Cu15/K0.9 & 935.3 & - & $\begin{array}{l}531.2(41 \%) \\
532.9(59 \%)\end{array}$ & 75.0 & 50.5 & 0.16 & 1.88 \\
\hline HT600-Co15 & - & 780.6 & $\begin{array}{l}529.3(40 \%) \\
530.7(60 \%)\end{array}$ & 74.8 & 50.5 & 0.48 & 1.10 \\
\hline HT800-Co15 & - & 780.3 & $\begin{array}{l}529.0(53 \%) \\
530.2(47 \%)\end{array}$ & 75.0 & 50.5 & 0.29 & 0.54 \\
\hline HT800-Co15/K0.9 & - & 780.3 & $\begin{array}{l}528.7(36 \%) \\
530.4(64 \%)\end{array}$ & 74.6 & 50.5 & 0.75 & 2.68 \\
\hline
\end{tabular}

${ }^{\mathrm{a}} \mathrm{M}=\mathrm{Cu}$ or $\mathrm{Co}$ 


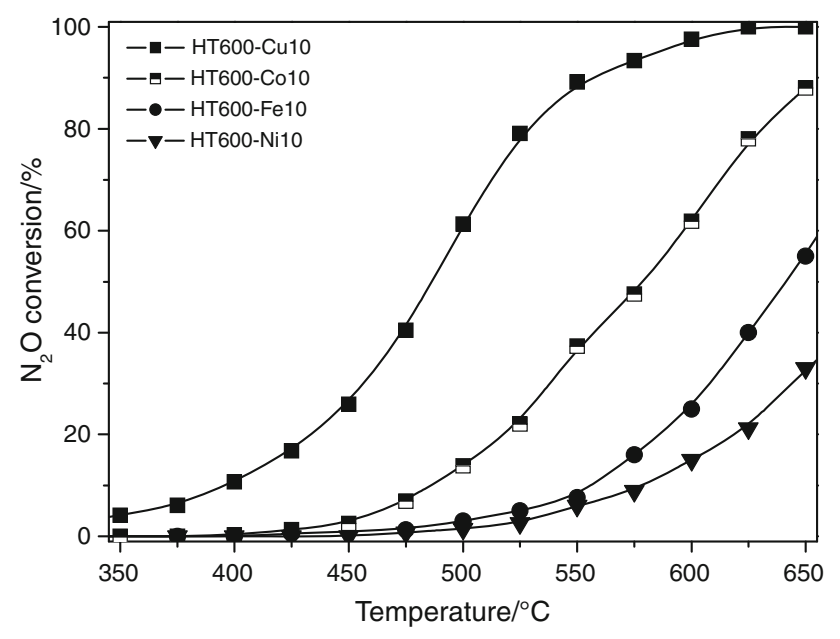

Fig. 4 Results of catalytic tests performed for the samples containing $\mathrm{Cu}, \mathrm{Co}, \mathrm{Fe}$, and $\mathrm{Ni}$ calcined at $600^{\circ} \mathrm{C}$

detailed studies were focused on the optimization of their chemical and phase composition.

Figure 5 shows the results of the catalytic studies for the samples containing copper (Fig. 5a), cobalt (Fig. 5b), or both copper and cobalt (Fig. 5c) calcined at 600, 700, or $800{ }^{\circ} \mathrm{C}$. Increasing the calcination temperature of the copper-containing sample from 600 to $800{ }^{\circ} \mathrm{C}$ significantly decreased its catalytic activity. An opposite effect was observed for the cobalt and copper-cobalt-containing samples. For a series of the HT-Co15 catalysts, an increase in the calcination temperature from 600 to $700{ }^{\circ} \mathrm{C}$ only slightly increased activity whereas a very significant activation of the catalyst occurred after calcination at $800{ }^{\circ} \mathrm{C}$. For the catalysts containing both copper and cobalt a distinct improvement in the catalytic activity was observed for the sample calcined at $700{ }^{\circ} \mathrm{C}$. An increase of the calcination temperature from 700 to $800{ }^{\circ} \mathrm{C}$ also resulted in the activation of the catalyst, however, this effect was not so significant. In the series of the catalysts calcined at various temperatures the highest activity was obtained for the copper-cobalt-containing sample calcined at $800{ }^{\circ} \mathrm{C}$.

As it was shown by XRD, UV-vis-DRS, and XPS analysis, the phase composition and textural parameters of the samples strongly depends on calcination temperature. An increase in the calcination temperature favors the formation of the spinel phases and additionally significantly decreases the surface area of the samples. For a series of the HT-Cu15 catalysts, a decrease of activity was observed for the samples calcined at increased temperatures. This effect could be explained by a decrease of the surface area of the samples and possibly also by lower activity of copper incorporated into the spinel structures. An increase in the calcination temperature decreased also the surface area of the cobalt containing samples (HT-Co15 series), however, despite this effect the samples calcined at 700 and $800{ }^{\circ} \mathrm{C}$ were significantly more catalytically active than that calcined at $600{ }^{\circ} \mathrm{C}$. This suggests that cobalt cations incorporated into the spinels structures are much more catalytically active than these present in the other forms. The interesting results were obtained for the samples containing both copper and cobalt. Taking into account the results obtained for the samples containing only one transition metal $(\mathrm{Cu}$ or $\mathrm{Co})$ it could be expected that an increase in the calcination temperature should result in transformation of copper into less catalytically active species whereas an opposite effect should be observed for cobalt. Therefore, the expected catalytic activity of the HT800-Cu10Co10 sample should be between the HT800Cu15 and HT800-Co15 catalysts whereas our studies showed the following activity order: HT800-Cu10Co10 > HT800-Co15 > HT800-Cu15. It seems that there is the synergetic effect related to the simultaneous presence of copper and cobalt oxides.

It was reported that promotion of the various transition metal oxide-based catalysts with alkali metals salts resulted in their activation in the $\mathrm{N}_{2} \mathrm{O}$ decomposition reaction [32]. The influence of potassium addition on the catalytic activity was studied for the hydrotalcite samples calcined at $800{ }^{\circ} \mathrm{C}$. The results of catalytic tests performed for the HT800-Cu15, HT800-Co15, and HT800-Cu10Co10 samples and their modifications with different loading of potassium $(0.09$ or $0.9 \mathrm{wt} \%)$ are shown in Fig. 6. It should be noted that introduction of potassium activated the catalysts in the $\mathrm{N}_{2} \mathrm{O}$ decomposition. The most significant increase in the catalytic activity was found for the copper-containing sample. In this case, the potassium loading strongly influenced the activity of the catalysts. For the HT800-Co15 sample, deposition of lower amount of potassium (0.09 wt\%) resulted in a slight deactivation of the catalyst, whereas a significant increase in activity was observed for the sample with higher content of potassium $(0.9 \mathrm{wt} \%)$. An introduction of potassium into the HT800-Cu10Co10 catalyst improved its activity, however, the activation effect was less significant than in the case of the other samples. As the catalysts are characterized by various specific surface area the reaction rate measured at $450{ }^{\circ} \mathrm{C}$ and related to this parameter of the samples is presented in Table 3. It should be noted that the reaction rate increased after deposition of potassium, however, this effect was less significant for the samples promoted with $0.09 \%$ of potassium and much more significant for the catalyst modified with $0.9 \%$ of this alkali promoter. Promotion effect of potassium on decomposition of $\mathrm{N}_{2} \mathrm{O}$ over various metal oxide catalysts was reported in literature. Xue et al. [13] explained the increased activity of the potassium-doped $\mathrm{Co}_{3} \mathrm{O}_{4}-\mathrm{CeO}_{2}$ catalyst by improvement of the redox properties of $\mathrm{Co}_{3} \mathrm{O}_{4}$ by small amount of alkali metal. Similar explanation of activation effect was proposed by Asano et al. [32] for potassium-doped $\mathrm{Co}_{3} \mathrm{O}_{4}$ catalyst. However, in this 

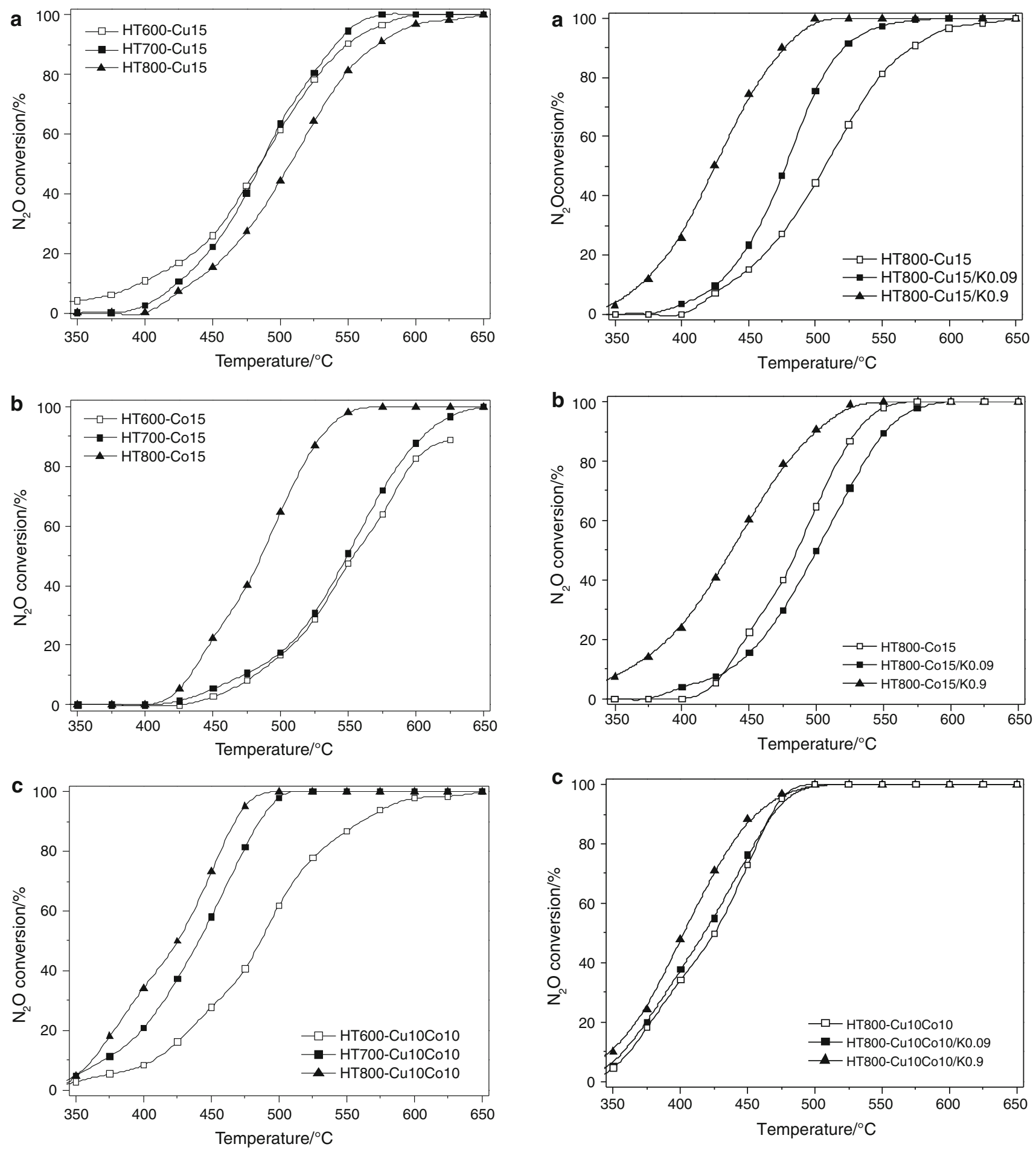

Fig. 5 Results of catalytic tests performed for the samples calcined at 600, 700, and $800{ }^{\circ} \mathrm{C}$, a HT-Cu15, b HT-Co15, and c HT-Cu10Co10

case authors suggest that potassium promotes mainly reoxidation of $\mathrm{Co}^{2+}$ to $\mathrm{Co}^{3+}$. According to Obalova et al. [33], the promotion of the catalytic activity of the samples is due to an increase in the electron density on the Co sites by addition of potassium. This effect forces the electron donation to the

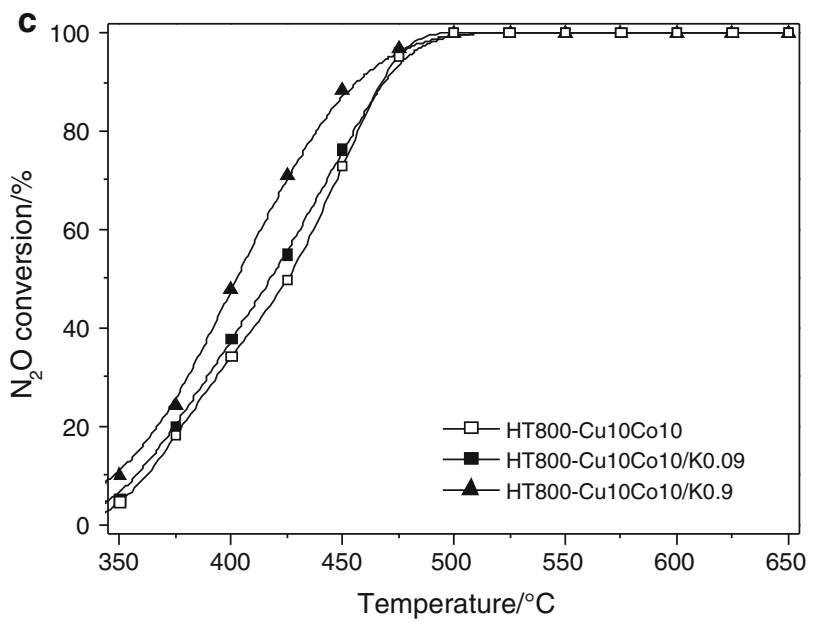

Fig. 6 Results of catalytic tests performed for the samples calcined in $800{ }^{\circ} \mathrm{C}$, modified by different amount of potassium, a HTCu15, b HTCo15, and c HTCu10Co10

adsorbed $\mathrm{N}_{2} \mathrm{O}$, and avail fast $\mathrm{N}_{2} \mathrm{O}$ chemisorption and fast desorption of oxygen. Haneda et al. [34] reported that doping alkali metals into the cobalt oxide catalysts can weaken the $\mathrm{Co}-\mathrm{O}$ bond strength and promote oxygen desorption from $\mathrm{Co}_{3} \mathrm{O}_{4}$. These authors suggested also that the low 
Table 3 Reaction rate determined at $450{ }^{\circ} \mathrm{C}$

\begin{tabular}{|c|c|c|c|c|c|}
\hline Catalyst & $\begin{array}{l}\text { Reaction } \\
\text { rate } / \times 10^{9} \mathrm{~mol} \\
\mathrm{~N}_{2} \mathrm{O} \mathrm{s}^{-1} \mathrm{~m}^{-2}\end{array}$ & Catalyst & $\begin{array}{l}\text { Reaction } \\
\text { rate } / \times 10^{9} \\
\operatorname{molN}_{2} \mathrm{O} \mathrm{s}^{-1} \mathrm{~m}^{-2}\end{array}$ & Catalyst & $\begin{array}{l}\text { Reaction } \\
\text { rate } / \times 10^{9} \mathrm{~mol} \\
\mathrm{~N}_{2} \mathrm{O} \mathrm{s}^{-1} \mathrm{~m}^{-2}\end{array}$ \\
\hline HT800-Cu15 & 2.96 & HT800-Co15 & 6.71 & HT800-Cu10Co10 & 20.67 \\
\hline HT800-Cu15/K0.09 & 4.97 & HT800-Co15/K0.09 & 4.41 & HT800-Cu10Co10/K0.09 & 23.25 \\
\hline HT800-Cu15/K0.9 & 17.42 & HT800-Co15/K0.9 & 20.03 & HT800-Cu10Co10/K0.9 & 29.23 \\
\hline
\end{tabular}

electronegativity of potassium may promote the electron transition from the active site to antibonding orbital of $\mathrm{N}_{2} \mathrm{O}$ and therefore facilitate the breaking the $\mathrm{N}-\mathrm{O}$ bound. Similar mechanism of the potassium promotion effect was suggested by Cheng et al. [35] for the $\mathrm{Co}-\mathrm{Al}$ catalysts prepared from hydrotalcite-like precursors.

\section{Conclusions}

Magnesium-aluminum hydrotalcite-like materials containing additionally cobalt, copper, nickel, and iron were synthesized and calcined at various temperatures. It was shown that an increase in calcination temperature promoted the formation of the spinel phases. The calcined hydrotalcites were studied in the role of the catalysts for $\mathrm{N}_{2} \mathrm{O}$ decomposition. Among the samples calcined at $600{ }^{\circ} \mathrm{C}$ the best results were obtained for the copper-containing catalysts. An increase in the calcination temperature to $700{ }^{\circ} \mathrm{C}$ significantly activated the cobalt-containing catalysts, while the opposite effect was found for the samples containing copper. Among the samples calcined at $800{ }^{\circ} \mathrm{C}$ the best results were obtained for the catalysts containing simultaneously both cobalt and copper. The activation of the cobalt-containing samples was related to the formation of the catalytically active spinel phases. An additional activation effect was observed after promotion of the samples with potassium, however, the copper-containing samples were activated much more effectively than the other catalysts.

\begin{abstract}
Acknowledgements This work was supported by the International $\mathrm{PhD}$ studies programme at the Faculty of Chemistry Jagiellonian University within the Foundation for Polish Science MPD Programme co-financed by the EU European Regional Development Fund. The research was carried out with the equipment purchased thanks to the financial support of the European Regional Development Fund in the framework of the Polish Innovation Economy Operational Program (contract no. POIG.02.01.00-12-023/08).
\end{abstract}

Open Access This article is distributed under the terms of the Creative Commons Attribution Noncommercial License which permits any noncommercial use, distribution, and reproduction in any medium, provided the original author(s) and source are credited.

\section{References}

1. Cavani F, Trifirò F, Vaccari A. Hydrotalcite-type anionic clays: preparation, properties and applications. Catal Today. 1991;11: 173-301.

2. Chmielarz L, Kuśtrowski P, Rafalska-Łasocha A, Dziembaj R. Influence of $\mathrm{Cu}, \mathrm{Co}$ and $\mathrm{Ni}$ cations incorporated in brucite-type layers on thermal behaviour of hydrotalcites and reducibility of the derived mixed oxide systems. Thermochim Acta. 2003;395: 225-36.

3. Chmielarz L, Kuśtrowski P, Rafalska-Łasocha A, Majda D, Dziembaj R. Catalytic activity of $\mathrm{Co}-\mathrm{Mg}-\mathrm{Al}, \mathrm{Cu}-\mathrm{Mg}-\mathrm{Al}$ and $\mathrm{Cu}-\mathrm{Co}-\mathrm{Mg}-\mathrm{Al}$ mixed oxides derived from hydrotalcites in SCR of NO with ammonia. Appl Catal B. 2002;35:195-210.

4. Ye L, Firdaus A. High temperature adsorption of carbon dioxide on $\mathrm{Cu}-\mathrm{Al}$ hydrotalcite-derived mixed oxides: kinetics and equilibria by thermogravimetry. J Therm Anal Calorim. 2009;97: $885-9$.

5. Voyer N, Soisnard A, Palmer SJ, Martens WM, Frost RL. Thermal decomposition of the layered double hydroxides of formula $\mathrm{Cu}_{6} \mathrm{Al}_{2}(\mathrm{OH})_{16} \mathrm{CO}_{3}$ and $\mathrm{Zn}_{6} \mathrm{Al}_{2}(\mathrm{OH})_{16} \mathrm{CO}_{3}$. J Therm Anal Calorim. 2009;96:481-5.

6. Bakon KH, Palmer SJ, Frost RL. Thermal analysis of synthetic reevesite and cobalt substituted reevesite $(\mathrm{Ni}, \mathrm{Co}) 6 \mathrm{Fe}_{2}(\mathrm{OH}) 16$ $\left(\mathrm{CO}_{3}\right) \cdot 4 \mathrm{H}_{2} \mathrm{O}$. J Therm Anal Calorim. 2010;100:125-31.

7. Chmielarz L, Kuśtrowski P, Rafalska-Łasocha A, Dziembaj R. Selective oxidation of ammonia to nitrogen on transition metal containing mixed metal oxides. Appl Catal B. 2005;58:235-44.

8. Christensen KO, Chen D, Lødeng R, Holmen A. Effect of supports and Ni crystal size on carbon formation and sintering during steam methane reforming. Appl Catal A. 2006;314:9-22.

9. Balasamy RJ, Khurshid A, Al-Ali AAS, Atanda LA, Sagata K, Asamoto M, Yahiro $\mathrm{H}$, Nomura K, Sano T, Takehira K, Al-Khattaf SS. Ethylbenzene dehydrogenation over binary $\mathrm{FeO}_{x}-$ $\mathrm{MeO}_{y} / \mathrm{Mg}(\mathrm{Al}) \mathrm{O}$ catalysts derived from hydrotalcites. Appl Catal A. 2010;390:225-34.

10. Cherlam U, Xu ZP, Zeng HC. Catalytic decomposition of $\mathrm{N}_{2} \mathrm{O}$ over $\mathrm{M}_{x} \mathrm{Co}_{1-x} \mathrm{Co}_{2} \mathrm{O}_{4}(\mathrm{M}=\mathrm{Ni}, \mathrm{Mg})$ spinel oxides. Chem Mater. 2000;12:650-8.

11. Yan L, Ren T, Wang XL, Ji D, Suo JS. Catalytic decomposition of $\mathrm{N}_{2} \mathrm{O}$ over $\mathrm{M}_{x} \mathrm{Co}_{1-x} \mathrm{Co}_{2} \mathrm{O}_{4}(\mathrm{M}=\mathrm{Ni}, \mathrm{Mg})$ spinel oxides. Appl Catal B. 2003;45:85-90.

12. Russo N, Fino D, Saracco S. $\mathrm{N}_{2} \mathrm{O}$ catalytic decomposition over various spinel-type oxides. Catal Today. 2007;119:228-32.

13. Xue L, Zhang C, He H, Teraoka Y. Catalytic decomposition of $\mathrm{N}_{2} \mathrm{O}$ over $\mathrm{CeO}_{2}$ promoted $\mathrm{Co}_{3} \mathrm{O}_{4}$ spinel catalyst. Appl Catal B. 2007;75:167-74.

14. Dandekar A, Vannice MA. Determination of the dispersion and surface oxidation states of supported Cu catalysts. J Catal. 1998; 179:111-28.

15. Centi G, Cerrato G, D'Angelo S, Finardi U, Giamello K, Morterra C, Perathoner S. Catalytic behavior and nature of active 
sites in copper-on-zirconia catalysts for the decomposition of $\mathrm{N}_{2}$ O. Catal Today. 1996;27:265-70.

16. Chmielarz L, Kuśtrowski P, Kruszec M, Dziembaj R, Cool P, Vansant EF. Nitrous oxide reduction with ammonia and methane over mesoporous silica materials modified with transition metal oxides. J Por Mater. 2005;12:183-91.

17. Armor JN, Braymer TA, Farris TS, Li Y, Petrocelli FP, Weist EL, Kannan S, Swamy CS. Calcined hydrotalcites for catalytic decomposition of $\mathrm{N}_{2} \mathrm{O}$ in simulated process streams. Appl Catal B. 1996;7:397-406.

18. Pacultova K, Obalova L, Kovanda F, Jiratova K. Catalytic reduction of nitrous oxide with carbon monoxide over calcined Co-Mn-Al hydrotalcite. Catal Today. 2008;137:385-9.

19. Obalova L, Jiratova K, Kovanda F, Pacultova K, Lacny Z, Mikulova Z. Catalytic decomposition of nitrous oxide over catalyst prepared from $\mathrm{Co} / \mathrm{Mg}-\mathrm{Mn} / \mathrm{Al}$ hydrotalcite-like compounds. Appl Catal B. 2005;60:289-97.

20. Obalova L, Pacultova K, Balabanova J, Jiratova K, Bastil Z, Valaskova M, Lacny Z, Kovanda F, Mikulova Z. Effect of Al/Mn ratio in $\mathrm{Co}-\mathrm{Mg}-\mathrm{Al}$ mixed oxide catalyst prepared from hydrotalcite-like precursors on catalytic decomposition of $\mathrm{N}_{2} \mathrm{O}$. Catal Today. 2007;119:233-8.

21. Chang KS, Lee H-J, Park Y-S, Woo J-W. Enhanced performance of $\mathrm{N}_{2} \mathrm{O}$ destruction in the presence of $\mathrm{CO}$ over the mixed metal oxide catalysts derived from hydrotalcite-like precursors. Appl Catal A. 2006;309:129-38.

22. Kannan S, Swamy CS. Catalytic decomposition of nitrous oxide over calcined cobalt aluminium hydrotalites. Catal Today. 1999;53:725-37.

23. Auer SM, Wandeler R, Göbel U, Baiker A. Heterogeneous coupling of phenylethyne over $\mathrm{Cu}-\mathrm{Mg}-\mathrm{Al}$ mixed oxides: influence of catalyst composition and calcination temperature on structural and catalytic properties. J Catal. 1997;169:1-12.

24. Enache DI, Rebours B, Roy-Auberger M, Revel R. In situ XRD study of the influence of thermal treatment on the characteristics and the catalytic properties of cobalt-based Fischer-Tropsch catalysts. J Catal. 2002;205:346-53.
25. Perez-Ramırez J, Mul G, Kapteijn F, Moulijn JA. On the stability of the thermally decomposed $\mathrm{Co}-\mathrm{Al}$ hydrotalcite against retrotopotactic transformation. Mater Res Bull. 2001;36:1767-75.

26. Herrero M, Benito P, Labajos FM, Rives V. Stabilization of $\mathrm{Co}^{2+}$ in layered double hydroxides (LDHs) by microwave-assisted ageing. J Solid State Chem. 2007;180:873-84.

27. Lim L, Ciuparu D, Park C, Dobek F, Chen Y, Harding D, Pfefferie L, Haller G. Synthesis and characterization of highly ordered Co-MCM-41 for production of aligned single walled carbon nanotubes (SWNT). J Phys Chem B. 2003;107:11048-56.

28. Crivello M, Perez C, Herrero E, Ghione G, Casuscelli S, Rodriguez-Castellon E. Characterization of $\mathrm{Al}-\mathrm{Cu}$ and $\mathrm{Al}-\mathrm{Cu}-\mathrm{Mg}$ mixed oxides and their catalytic activity in dehydrogenation of 2-octanol. Catal Today. 2007;107-108:215-22.

29. Strohmeier BR, Leyden DE, Field RS, Hercules DM. Surface spectroscopic characterization of $\mathrm{Cu} \mathrm{Al}_{2} \mathrm{O}_{3}$ catalysts. J Catal. 1985;94:514-30.

30. Chuang TJ, Brundle CR, Rice DW. Interpretation of the x-ray photoemission spectra of cobalt oxides and cobalt oxide surfaces. Surf Sci. 1976;59:413-29.

31. Bridier B, Lopez N, Perez-Ramirez J. Partial hydrogenation of propyne over copper-based catalysts and comparison with nickelbased analogues. J Catal. 2010;269:80-92.

32. Asano $\mathrm{K}$, Ohnishi $\mathrm{C}$, Iwamoto $\mathrm{S}$, Shioya $\mathrm{Y}$, Inoue M. Potassiumdoped $\mathrm{Co}_{3} \mathrm{O}_{4}$ catalyst for direct decomposition of $\mathrm{N}_{2} \mathrm{O}$. Appl Catal B. 2008;78:242-9.

33. Obalova L, Karaskova K, Jiratova K, Kovanda F. Effect of potassium in calcined $\mathrm{Co}-\mathrm{Mn}-\mathrm{Al}$ layered double hydroxide on the catalytic decomposition of $\mathrm{N}_{2} \mathrm{O}$. Appl Catal B. 2009;90: $132-40$.

34. Haneda M, Kintaichi Y, Bion N, Hamada H. Alkali metal-doped cobalt oxide catalysts for $\mathrm{N}_{2} \mathrm{O}$ decomposition. Appl Catal B. 2003;46:473-82.

35. Cheng H, Huang Y, Wang A, Li L, Wang X, Zgang T. $\mathrm{N}_{2} \mathrm{O}$ decomposition over K-promoted $\mathrm{Co}-\mathrm{Al}$. Catalysts prepared from hydrotalcite-like precursors. Appl Catal B. 2009;89:391-7. 